\title{
PEREGRINAS E INAUDITAS INVENÇÕES: PRIMEIROS CAMINHOS DA IMAGEM
}

\author{
Enivalda Nunes Freitas e Souza ${ }^{1}$ \\ Elzimar Fernanda Nunes Ribeiro ${ }^{2}$
}

Em seu número inaugural, a Téssera - Revista do GT da ANPOLL "Imaginário, representações literárias e deslocamentos culturais" se apresenta composta por artigos cujo aporte teórico recaem sobretudo em Carl Gustav Jung, Gaston Bachelard, Joseph Campbell, Mircea Eliade e Gilbert Durand. Coube a este último uma sistematização da crítica do imaginário nos termos da mitocrítica, um método de investigação que promove o entrelaçamento da cultura com a arte, concebendo uma hermenêutica do texto literário a partir das imagens, dos símbolos e dos mitos que se manifestam na sua tessitura.

Ancorando-se no paradigma antropológico que permite observar na arte a universalidade das formas arquetípicas e seus valores simbólicos flutuantes e intercambiáveis, Durand (2002) lança os fundamentos da mitocrítica em A estruturas antropológicas do imaginário. Por outro lado, em O imaginário (2004), o estudioso assinala o desprestígio que a imaginação sofreu no ocidente. Custa ao racionalismo ocidental aferirlhe o estatuto de portadora de verdades, geralmente atribuído ao pensamento lógico. Neste sentido, a reabilitação da via do imaginário como fonte de saber antropológico, na cultura ocidental, tem sido operada em grande medida pelos artistas, desde os poetas-filósofos préromânticos alemães em fins do século XVIII, passando pelos simbolistas, até a sua explosão no Surrealismo.

E, no entanto, sendo a imaginação tão cara e inerente aos seres humanos, é enganoso supor que só a partir do século XVIII, filósofos, poetas e teósofos passaram a considerá-la em seus trabalhos. Antes de se considerar a força de uma palavra inventada, o mito já havia

\footnotetext{
${ }^{1}$ Universidade Federal de Uberlândia (UFU), Graduação e Pós-Graduação. Coordenadora do GT "Imaginário, representações literárias e deslocamentos culturais" (ANPOLL). É autora do livro Flores de Perséfone: a poesia de Dora Ferreira da Silva e o sagrado (2013), e organizadora de Poesia com deuses: estudos de Hídrias, de Dora Ferreira da Silva (2016), além de coorganizadora das obras Roteiro poético de Hilda Hilst (2009) e Sonho de um repentista - versos do poeta logogrífico Canelinha (2009). eni@ufu.br

2 Universidade Federal de Uberlândia (UFU), Graduação e Pós-Graduação. Vice-coordenadora do GT "Imaginário, representações literárias e deslocamentos culturais". Coeditou o Dossiê "Imaginário, representações literárias e deslocamentos culturais" (2015), da Revista Letras \& Letras (EDUFU). É autora de capítulos como "O antigo Portugal no Brasil renascido?: o mito do império luso-brasileiro em Caramuru, de Santa Rita Durão" (2014). elzimar.fernanda@ufu.br
} 
Peregrinas e inauditas invenções: primeiros caminhos da imagem

despontado como força criadora da arte, como imagem encobridora de verdades profundas. Essas histórias atemporais já criavam na imagem do belo moço impetuoso, Bóreas - que desviava discos, roubava donzelas ou atirava outras em abismos - a imagem do vento. Nos mitos, a linguagem estava a serviço de uma fábula, era mais comunicativa, não sofria, de modo geral, contorcimentos que turvassem o entendimento. Mas pouco a pouco a poesia aqui concebida como a arte da escrita ficcional em qualquer gênero - foi reivindicando a sua primeira linguagem, aquela que se reinventava, banhada pela imaginação, para dar conta de realidades insuspeitadas. Nas páginas seguintes, percorreremos alguns pensadores que se esforçaram na defesa da imagem e do símbolo antes que investigações renovadoras nas áreas da psicologia, da filosofia, da antropologia e das artes desestabilizassem as premissas que constituíram a modernidade, vindo assim a conceber, de vez, a imaginação como o principal foco criador da mente humana.

\section{Antes dos pré-românticos, de Bachelard e de Jung}

Se a palavra poética será tomada como uma imagem simbólica da natureza, é preciso lembrar Heráclito e sua noção de lógos, a conjunção entre pensamento e natureza (phýsis) que percebe o cosmos a partir da Unidade que preserva as diferenças, mantendo os opostos numa integralidade em cuja harmonia cada coisa juntada permanece enquanto tal, mas se faz homóloga às outras. Os poetas estão entre aqueles que podem revelar o que está oculto na natureza porque ouvem, sabem escutar o lógos por trás das coisas aparentes. Daí que a linguagem de Heráclito, tal como a dos poetas, seja considerada obscura e ambígua. Em conformidade com a phýsis que só mostra o aparente, a linguagem também se turva, uma vez que o poeta pensa com todos os sentidos, em constante mobilidade, como se pode inferir dos fragmentos 104 e 105: “ 104 - O senhor, de quem é o oráculo, aquele em Delfos, não diz nem oculta, porém, assinala”. "105 - Com delirante boca, sem risos, sem pinturas e sem bálsamos, emite a Sibila através do deus a voz que ultrapassa mil anos" (HERÁCLITO, 2012, p. 159).

No século XIV, em 1366, o florentino Giovanni Boccaccio (1313-1375) defende que, sob fervor, a poesia inventa com esmero e leva "a imaginar peregrinas e inauditas invenções". O furor, o estado de possessão, propicia a tessitura de palavras que encobrem "a verdade com um véu de fábula e formosura", por isso não pode ser depreciada. Bocaccio 
Peregrinas e inauditas invenções: primeiros caminhos da imagem

argumenta que o poeta assim procede não para se apresentar mais destro em seu ofício, "mas para tornar objeto do labor dos engenhos as coisas envilecidas por excessiva exposição, as quais, compreendidas de modo diverso, se fazem então mais caras" (BOCCACCIO, 2014, p. 863). ${ }^{3}$ Em muitos pensadores vai aparecer essa função do poeta ao criar imagens, a de rejuvenescer a língua, arejá-la, revigorá-la, como defenderá Bachelard séculos mais tarde. Sobre o sentido obscuro que tais arranjos dão às palavras comuns - "vulgares e domésticas" - , transformando-as em "palavras peregrinas", de beleza desconhecida, Boccaccio aconselha que os leitores as investiguem, porque "licenças para tais coisas foram dadas aos poetas". Se o leitor se entregar ao exercício da imaginação, "o que agora parece obscuro então lhes parecerá familiar e aberto".

A ideia do familiar e aberto se instaura após o estranhamento comum à linguagem poética, diferente da linguagem oral, insiste. Após esse exercício, formas, costumes, discursos, tudo se revela: "as alturas das montanhas, as sombras dos bosques e o fluir dos rios, descritos com tal propriedade que pensarão que tudo isso está inscrito nas pequenas letrinhas dos versos" (BOCCACCIO, 2014, p. 865). Assim posto, a imaginação ocorre como via preferencial não apenas para o homem compreender o mundo (implicando um exercício de hermenêutica do ser por via da linguagem simbólica), mas também para fruí-lo, posto que lhe desvela um sentido.

Em fins do século XVI, precisamente em 1583, o britânico Philip Sidney (15541586) faz o "Elogio da poesia", afirmando que ela foi "a primeira a lançar luzes sobre a ignorância". Ao ensinar, o poeta se valeu de imagens. Para argumentar sua defesa, Sidney evoca os mitos de Anfião e Orfeu: "conta-se que Anfião, para construir Tebas, moveu as pedras com sua poesia, e que Orfeu era ouvido pelas bestas - na verdade gente de pedra e bestial”. (SIDNEY, 2014, p. 895). Quase quatro séculos depois, Carl Gustav Jung vai depositar no mito a força simbólica que ativa no inconsciente resíduos de vivências psíquicas coletivas, patrimônio da humanidade que a arte resgata no processo criador.

\footnotetext{
${ }^{3}$ Roberto Acízelo de Souza organizou a obra monumental Do mito das musas à razão das letras, textos seminais para os estudos literários (Século VIII a. C. - século XVIII). O resgate dos pensadores sobre a imagem e o símbolo, que compõem as páginas que ora se iniciam, só foi possível graças à pesquisa nas 1.700 páginas que o pesquisador apresenta em torno dos "textos seminais para os estudos literários". A primeira coletânea composta pelo pesquisador foi intitulada Uma ideia moderna de literatura e também será consultada mais adiante. Registre-se, ainda, que o professor Roberto Acízelo de Souza é o tradutor de muitos dos textos selecionados por ele.
} 
Peregrinas e inauditas invenções: primeiros caminhos da imagem

Centrando sua reflexão no poder da imagem, Sidney ressalta que ela "não é descrição palavrosa, ela é perfeita, pois penetra e arrebata os olhos da alma”. Na defesa da poesia, mostra que esta influenciou a filosofia de Platão, a beleza de seus diálogos. De igual modo, os historiadores também aprenderam com a poesia, herdaram as descrições das paixões e das batalhas e os discursos que põem na boca de personagens históricos, discursos que eles jamais pronunciaram. Desta forma, a "imagem fingida" tem mais força para instruir:

deixai porém que Sófocles vos traga Ájax a um palco, matando e açoitando carneiros e bois, tomando-os pelo exército dos gregos, com seus capitães Agamenon e Menelau, e dizei-me se não tereis uma visão mais audaciosa da cólera do que descobrindo nos escolásticos seu gênero e especificidade [...] virtudes, vícios e paixões se apresentam à vista com tal propriedade que nos parece não ouvir falar a seu respeito, mas claramente ver através deles. (SIDNEY, 2014, p. 906)

Philip Sidney não só defende a imagem como também se expressa valendo-se dela. O poeta é o monarca de todas as ciências porque apresenta o objeto antes do conceito: "se ele convida o leitor a percorrer um belo vinhedo, primeiro ele oferece um cacho de uvas saboroso que faz o leitor seguir adiante" (SIDNEY, 2014, p. 911). Essa postura antecede as concepções mais avançadas no tempo de que poesia é imagem, antecipa o postulado da teoria bachelardiana de que, na poesia, é a matéria que faz sonhar, imaginar. A ideia vem depois. Por fim, Sidney situa a linguagem do poeta para além do binômio clássico falso/verdadeiro, pois, enquanto a humanidade está envolta por uma nebulosa de mentiras, o poeta não afirma nada, então nunca mente. Além do mais, aponta: “o poeta nunca dá voltas na vossa imaginação para rogar-vos acreditar verdadeiro o que ele escreve” (SIDNEY, 2014, p. 920).

Em franca oposição ao pensamento aristotélico, Francis Bacon (1561-1626) discorre que a poesia se assenta na imaginação e que a razão aprisiona o espírito. Bacon considera a realidade sem magnitude, incapaz de preencher e satisfazer as necessidades espirituais do homem; antecipando assim a definição de imagem em Octavio Paz, segundo o qual a imagem desafia o princípio de contradição ao promover a junção daquilo que é objetivamente separado, como plumas e pedras, operando a transformação de que pedras são plumas. Bacon assegura:

[a poesia] decidida e verdadeiramente se relaciona com a imaginação, a qual, não estando atada às leis da realidade factual, pode a seu bel-prazer juntar o que a natureza separou, e separar o que ela juntou, e assim fazer combinações e separações de coisas ao arrepio daquelas leis (BACON, 2014, p. 933). 
Peregrinas e inauditas invenções: primeiros caminhos da imagem

A imaginação coloca o universo mais próximo da providência divina, porque a poesia finge justamente, isto é, junta as coisas que parecem separadas. O dom da analogia, e da homologia, embasa boa parte do conhecimento antropológico, incluindo todo o campo das formulações metafóricas. Como explicitará Durand mais à frente, a imaginação simbólica funda-se na lógica da homologia, inclusive articulando-se por meio de múltiplas relações de afinidade, que compõem grandes constelações de imagens.

Gian Vincenzo Gravina (1644-1718), em “Da razão poética”, texto de 1708, confere à imagem poética uma carga simbólica cuja potencialidade será base das teorias de Freud e Jung no século XX. O pensador italiano deposita na imagem a função de entrar em instâncias profundas da mente humana, para atingir as raízes que formam o conhecimento vulgar. Antecipando o que Jung dirá sobre a função do poeta de mergulhar no inconsciente coletivo, guardião das formas arquetípicas, e encontrar os símbolos adequados a seu tempo, Gravina fala em "cavar fundo" e "abrir por dentro das antigas fábulas uma senda oculta", porque lá estariam, veladamente, o fruto do encantamento da arte e sua finalidade. Pressentindo as inquietações mais profundas e incorpóreas do comportamento humano, o poeta molda sua arte - como diria Jung: traduz em símbolos compreensíveis - em imagens sensíveis:

Para que, por conseguinte, se possa aí penetrar, convém dispô-las de um modo proporcional às faculdades da imaginação, e em forma apta a entrar adequadamente naqueles moldes; para tanto, é preciso vesti-las com trajes materiais, e convertê-las em aspecto sensível, pulverizando o axioma universal nos seus indivíduos, de modo que, sendo fonte para suas torrentes, se espalhe e se esconda dentro delas, como no corpo o espírito. (GRAVINA, 2014, p. 984)

Em linhas seguintes, Gravina assinala que a imagem corpórea dá "vida" às contemplações, e é nessa aparência que está o poder de entrada "nas mentes vulgares". O poeta se apossa das fantasias e com as imagens poéticas converte o verdadeiro em fingido. Trabalhando simbolicamente, o poeta desperta em todos os homens suas verdades mais secretas, atingindo o verdadeiro pelo falso: "apossando-se das fantasias, com as imagens poéticas envolveram-nas no fingido, para aguçar a mente na direção do verdadeiro, que por dentro do fingido transparecia; de modo que as gentes, delirando, curavam-se das loucuras. (GRAVINA, 2014, p. 984) A seguir, Gravina recorre aos mitos para explicar a forma simbólica com que a arte opera: 
Peregrinas e inauditas invenções: primeiros caminhos da imagem

Para imprimir na consciência vulgar a angústia do ânimo agitado pelas próprias paixões, e remordido pelo dente da consciência do mal feito, evocaram as imagens das Fúrias vestidas de horror e de medo, para que, figuradas como chama e serpentes, fossem trazidas para fora das mentes vulgares aquelas paixões, que são expulsas da filosofia à força de vivas razões (GRAVINA, 2014, p. 984)

De igual modo, finaliza Gravina, "à força do mesmo encanto”, para domesticar os vícios humanos, trouxeram a avareza na imagem de Tântalo, aquele de fome e sede eternas: "tais sentimentos, por meio dessas imagens, os Poetas os incutiram nos peitos brutos". Com essa mesma arte com que expurgaram os vícios nos homens, os poetas "excitaram também nos povos a ideia da virtude" (GRAVINA, 2014, p. 985).

Joseph Addison (1672 - 1719), britânico, em "Sobre os prazeres da imaginação", texto de 1712, postula dois tipos de prazer proporcionados pela imaginação, aos quais nomeia de primários e secundários: os primários são aqueles derivados dos objetos frente a nossos olhos; os secundários são aqueles despertados pela memória "ou formulados em visões correspondentes de coisas ausentes ou fictícias". Também atribui uma função terapêutica à arte, afirmando que a imaginação cura a dor e a melancolia, uma vez que um homem de imaginação pode ter uma estátua por companhia e conversar com uma gravura (ADDISON, 2014, p. 990-991). Ao longo de sua explanação, Addison privilegia a faculdade ocular, lançando sobre essa uma capacidade maior de provocar prazer, isto é, aquilo que vemos aguça mais a imaginação do que aquilo que recordamos. No entanto, quando se trata da palavra poética, ela se apodera com mais vigor da realidade, provocando um desbotamento, um enfraquecimento das coisas mesmas:

Palavras, quando bem escolhidas, tem tamanha força em si que uma descrição muitas vezes nos dá ideias mais vívidas do que a própria vista das coisas mesmas [...] Nesse caso, o poeta parece apoderar-se do melhor da natureza; ele toma, de fato, a paisagem nos termos dela, mas lhe dá toques mais vigorosos, realça-lhe a beleza, e assim vivifica toda a peça, a fim de que as imagens que fluem dos objetos mesmos pareçam fracas e desmaiadas, em comparação com aquelas que vem da expressão. (ADDISON, 2014, p. 1001)

A imaginação provocada pela palavra escrita é mais vantajosa pela própria natureza das palavras, que abarcam mais de um sentido, ampliando a nossa imaginação: ao observarmos um objeto, só temos o que nossa vista alcança, ao passo que o poeta, ao projetar a imaginação, "descobre para nós diversas partes", dando-nos uma "ideia mais complexa". 
Peregrinas e inauditas invenções: primeiros caminhos da imagem

Um poeta de imaginação vigorosa, conclui Addison, sabe escolher as palavras mais expressivas, permitindo que se vislumbre coisas distintas nas mesmas descrições.

\section{Fundadores do Romantismo: Novalis e Schlegel}

Se o reconhecimento da imaginação enquanto faculdade apta para sondar o homem e a natureza não é uma criação pré-romântica, como se viu, é com o círculo alemão de Iena, no finalzinho do século XVIII, com Novalis, os irmãos Schlegel (August e Friedrich), Schiller, Schelling, fundindo filosofia e poesia, que se sacramenta o prestígio da imaginação no labor poético. A ânsia do absoluto e do infinito, a certeza de que o homem tomado por uma visão religiosa e mágica pode, pela imaginação, abarcar a totalidade das coisas, são legados que ainda repercutem na visão poética da vida. Pela imaginação, o universo está todo dentro de nós, dirá Novalis (1772-1801).

Em seus fragmentos, Novalis registra que a imaginação é o órgão máximo, a base de qualquer processo criador. A verdade sem a ilusão é deficiente, o que faz do mais poético o mais verdadeiro. No fragmento 21, define o gênio criador por essa capacidade: "Gênio é a faculdade de tratar de objetos imaginados como se se tratasse de objetos efetivos, e também de tratá-los como a estes" (NOVALIS, 2001, p. 48). Novalis aponta no fragmento 22 que esse processo de ver o inverso do pensamento racional é, por preconceito, negado ao ser humano, quando, na verdade, a todo instante ele pode estar além de seus sentidos. O estar fora de si leva a percepções múltiplas, que produzem incessantemente formas alteradas, aí reside a riqueza de espírito, escreve Novalis no fragmento 31 (NOVALIS, 2001, p. 55). O deslocamento arbitrário da percepção como uma riqueza para a compreensão da arte é um procedimento muito explorado na estética contemporânea, bem como a ideia de que só o incompleto leva à progressão, postulado no fragmento 151: "Só o incompleto pode ser concebido - pode levar-nos mais adiante. O completo é apenas fruído. Se queremos conceber a natureza, então temos de pô-la incompleta, para assim chegar a um termo alternativo desconhecido" (NOVALIS, 2001, p. 154).

O termo alternativo e desconhecido é a imagem-símbolo, o que por natureza se apresenta incompleto e apto a ser infinitamente remodelado, haja vista seu caráter nãoalegórico, uma vez que não pode ser explicada por outras palavras, conforme escreve no 
Peregrinas e inauditas invenções: primeiros caminhos da imagem

fragmento 185: "Imagem - não alegoria - não símbolo de algo alheio - símbolo de si mesma" (NOVALIS, 2001, p. 154).

Por sua vez, Friedrich Schlegel (1772-1829) rompe notavelmente com as premissas da arte clássica racionalista e, inclusive, desconsidera a possibilidade de se criar poesia através das faculdades da razão, declarando a inutilidade dos manuais de arte poética: "Não é preciso que alguém se empenhe em obter e reproduzir a poesia através de discursos e doutrinas racionais" (SCHLEGEL, 1994, p. 30). Schlegel considera que a poesia é nata ao homem, mas sua origem estaria posta sob a superfície clara e precisa da racionalidade, fincando suas raízes no âmago do espírito humano, assumindo assim uma qualidade ctônica:

Assim como o coração da terra se reveste de plantas e formas, assim como a vida brotou por si mesma das profundezas e tudo tornou-se pleno de criaturas que alegremente se multiplicavam, assim também brota espontânea a poesia da força primeva e invisível da humanidade, quando o cálido raio do sol divino atinge e fecunda. (SCHLEGEL, 1994, p. 30).

Se, com esta impressionante metáfora da criação poética, Schlegel parece antecipar o inconsciente (como concebido por Freud) numa outra metáfora contígua a esta, ao situar as matrizes desta fertilidade criadora em algum ponto fulgurante comum a todos nós, colocado ainda além da nossa irracionalidade individual, ele parece antecipar também as noções do arquétipo e do inconsciente coletivo junguianos:

Somos capazes de perceber a música do infinito mecanismo, de compreender a beleza do poema, porque em nosso íntimo também vive uma parte do poeta, uma fagulha de seu espírito criador, que bem debaixo das cinzas de nossa própria desrazão, nunca cessa de arder com secreta violência. (SCHLEGEL, 1994, p. 30, grifos nossos).

Para se obter um poema capaz de atingir toda a humanidade, o poeta teria que se lançar num duplo movimento: de se interiorizar em sua própria intimidade para, então, dele retornar de dentro para fora: “[...] o homem, seguro de que irá se reencontrar, volta-se sempre de novo para fora de si mesmo para obter o complemento de sua mais funda natureza nas profundezas de outrem" (SCHLEGEL, 1994, p. 30). Ora, tal método de composição poética, advogado por Schlegel, assemelha-se notavelmente à postura metodológica preconizada por Durand em seus estudos sobre a imaginação simbólica. Chamada de "trajeto antropológico" e caracterizada como um "caminhar reversível", ela consiste no postulado da "incessante troca que existe ao nível do imaginário entre as pulsões subjetivas e assimiladoras e as intimações objetivas que emanam do meio cósmico e social", a ponto de se estabelecer uma 
Peregrinas e inauditas invenções: primeiros caminhos da imagem

"gênese recíproca que oscila do gesto pulsional ao meio material e social e vice-versa" (DURAND, 2002, p. 41).

Não são poucas, como se vê, as contribuições visionárias de Schlegel quanto à compreensão da relação orgânica entre a poesia e a imaginação, mas provavelmente ela atinge seu clímax no breve ensaio "Discurso sobre mitologia", que o filósofo-poeta publicou originalmente numa revista literária ligada ao círculo de Iena. Assim, escrito no alvorecer do mundo moderno, o texto assinala que a poesia deste novo tempo não teria um cerne, um núcleo balizador e gerativo, como havia sido a mitologia clássica para a poesia dos gregos. Entretanto, Schlegel não se lamenta, ao contrário, ele pressente um futuro grandioso em que uma nova mitologia seria composta pelos novos poetas, afinal "mitologia e poesia são unas e inseparáveis" (SCHLEGEL, 1994, p. 51). A nova poesia sonhada pelo então jovem Schlegel poderia atingir e até exceder em beleza e grandiosidade a que nos legou a cultura grega, posto que embebida pela ilimitada fantasia do espírito, ultrapassando as fronteiras do racionalismo:

Pois este é o princípio de toda a poesia, superar o percurso e as leis da razão racionalmente pensante e transplantar-nos de novo para a bonita confusão da fantasia, o caos originário da natureza humana, para os quais não conheço, até agora, símbolo mais belo que a multidão colorida dos antigos deuses. (SCHLEGEL, 1994, p. 55).

Percebe-se então que Schlegel já pressentia toda a riqueza arquetípica dos símbolos representados na mitologia antiga, bem como sua notável potência de regenerar o espírito humano, ao lhe proporcionar a faculdade ímpar da metamorfose:

A mitologia é uma tal obra de arte da natureza. O mais elevado é de fato configurado em seu tecido, tudo é relação e metamorfose, formado e reformado, e estes formar e transformar são seu procedimento característico, sua vida interna, seu método, por assim dizer (SCHLEGEL, 1994, p. 55).

Lançando na conta do futuro o sonho desta nova mitologia, acessada pela via do imaginário poético, "Schlegel transfigura o mito em energia utópica e investe a mitopoesia de um poder mágico" (LÖWY; SAYRE, 1995, p. 58). E então Schlegel sonha que, no mundo moderno, a criação poética viesse a ser a morada e a matriz de uma nova mitologia capaz de rejuvenescer a humanidade, reencantar o mundo do homem e levá-lo a desfrutar plenamente da "força divinatória" guardada em sua mente. 
Peregrinas e inauditas invenções: primeiros caminhos da imagem

\section{Símbolos}

No texto "Símbolos", de 1831, Thomas Carlyle (1795-1881), ensaísta britânico que pensou a arte "sob a influência do idealismo alemão" (SOUZA, 2011, p. 141), antecipa a sistematização junguiana da ideia de símbolo como tradução dos extratos mais profundos da psique humana, sendo o símbolo composto por uma parte conhecida, pronta a falar ao nosso entendimento, e outra parte desconhecida, a que evoca sentidos para além do conhecido. E é justamente essa parte desconhecida, envolta por "encobrimento", "silêncio e segredo" (seu valor extrínseco) que é eficaz, afirma Carlyle (2011, p. 141). Mais adiante, acentua que a parte silenciosa do símbolo é que permite sua dupla significação:

A ação prodigiosa dos Símbolos se aparenta com a incalculável influência do Encobrimento, e se associa a coisas ainda maiores. Num Símbolo há encobrimento e, todavia, revelação: aqui, portanto, pela ação conjunta do Silêncio e da Fala, surge uma dupla significação. (CARLYLE, 2011, p. 142)

Com tal visão sobre a abrangência do pensamento não racional, que valoriza as imagens encobertas, Carlyle escreve, sem meias palavras, o alcance da imaginação, que pode salvar e condenar a humanidade: "Sim, Amigos, [...] não a faculdade Lógica e Mensurativa, mas a Imaginativa é que é nossa Soberana; poderia dizer, Sacerdotisa e Profetisa que nos leve para o céu; ou mágica e feiticeira que nos leve para o inferno (CARLYLE, 2011, p. 143). Lembrando o pensamento do espiritualista sueco Emanuel Swedenborg (1688-1772), Carlyle afirma que de forma consciente ou inconsciente, o homem vive entre símbolos, revelação "mais obscura ou mais clara do Divino" (CARLYLE, 2011, 142).

Não passou despercebido a Carlyle a ideia de que o tempo acaba desgastando os símbolos, desfigurando-os, produzindo símbolos gastos. Muito em breve, o tempo transforma a novidade e o mistério do símbolo em signo: "como todas as vestimentas terrenas, tornam-se velhos" (CARLYLE, 2011, p. 144). Lentamente, os poetas vão removendo os símbolos desgastados e renovando o fogo da palavra profanada: "O Poeta e Criador inspirado; que, como Prometeu, pode configurar novos Símbolos, e trazer fogo novo do Céu para lá colocá-lo" (CARLYLE, 2011, p. 145).

Enquanto isso, do outro lado do atlântico, o americano Ralph Waldo Emerson (18031882) dá um passo à frente, ao frisar no ensaio "O poeta", de 1844, o caráter integralizador da natureza do símbolo, que abole todas as diferenças, unindo hierarquias e qualidades 
Peregrinas e inauditas invenções: primeiros caminhos da imagem

distintas, como o superior e o inferior, os honestos e os vis: "O pensamento torna todas as coisas adequadas ao uso" (EMERSON, 2011, p. 174).

Sob declarada influência de Swedenborg, Emerson vê a natureza como uma linguagem figurada, um grande símbolo, "no todo e em cada uma das partes", sendo o poeta o responsável por realçar-lhe "um segundo valor". Na verdade, o poeta não rafia nada mais que seguir o exemplo da natureza: "As coisas admitem ser usadas como símbolos porque a Natureza é um símbolo" (EMERSON, 2011, p. 172). Nesse jogo especular, até uma lista de palavras torna-se sugestiva (Mallarmé e a palavra sem sentido!): "Toda nova relação é uma nova palavra" (EMERSON, 2011, p. 174). É o trabalho poético que recupera o caráter original das palavras, esquecidas de seu valor simbólico pelo uso, de modo a conferir vida às coisas inanimadas. Acertar com o emprego das palavras é falar insensatamente, coisa que só o poeta compreende. Por isso os poetas são "deuses libertadores", propiciam uma nova visão de mundo. A imaginação simbólica presta melhor serviço do que os livros didáticos, emancipa os homens, devolvendo-lhes a alegria: "Parece que somos tocados por uma vara de condão, que nos faz dançar e correr à volta, felizes como crianças” (EMERSON, 2011, p. 178).

O ensaísta institui o poder de fluir como a maior qualidade da imaginação, afirmando que todos os símbolos são fluxionários. A razão congela, a imaginação dinamiza. O contínuo movimento e transformação do mundo é acompanhado pelo símbolo: “O poeta não se detém na cor ou na forma, mas lê-lhes o sentido; não se detém neste, mas faz dos mesmos objetos expoentes de seu novo pensamento" (EMERSON, 2011, p. 179). Em Swedenborg estaria a perfeita correspondência entre coisas e palavras, isto é, as coisas simbolizam palavras, em perpétua metamorfose: "Os figos se tornam uvas enquanto ele os come" (EMERSON, 2011, p. 180). Por fim, o caráter fundante e inaugural da palavra poética que refaz o mundo a partir dele mesmo: "Todas as criaturas, aos pares e em tribos, penetrarão em sua mente como na Arca de Noé, para ir povoar outa vez um novo mundo" (EMERSON, 2011, p. 181).

\section{Deformar para educar}

Nesta breve e incompleta historiografia, ainda poderíamos citar diversos outros visionários da imaginação, como William Blake, Tennyson, Schelling, Baudelaire, Lautréamont, para ficarmos nas sendas literárias. O pensamento percorreu um longo 
Peregrinas e inauditas invenções: primeiros caminhos da imagem

caminho para descobrir e compreender a palavra como potência simbólica. Românticos, simbolistas e surrealistas fizeram uso da linguagem buscando a verdade na desordem e no lado misterioso e desconhecido que subjaz ao olhar racionalista, assinalando a música e o sonho como estados propícios às emanações simbólicas. É no simbolismo que o poeta recebe, ainda uma vez, o epíteto de criador obscuro, o que levou Mallarmé a responder que sua arte com palavras não era página de jornal.

No "Manifesto do Surrealismo", de 1924, André Breton se debaterá contra o mau uso das palavras, pregando o seu embaralhamento para libertá-las: "A linguagem pode e deve ser arrancada a sua servidão" (BRETON, 1924), só assim o poeta poderá percorrer caminhos inusitados, não sem antes apontar na imaginação seu caráter ilimitado e caprichoso: "Imaginação querida, o que sobretudo amo em ti é não perdoares". Breton manifesta mesmo um horror à atitude realista, feita de mediocridade e de uma "suficiência vulgar”, pois considera apenas o que passa pela experiência. Note-se, que ligados ao movimento surrealista, surgirão diversos importantes teóricos do símbolo e da imagem, dentre os quais podemos destacar o francês René Alleau e o grande poeta-teórico mexicano Octavio Paz.

Breton lembra muito justamente que Freud deve ser agradecido por ter aberto essa porta por meio do sonho, liberando a artistas e pensadores o poder de investigar o que está além da aparência. No entanto, caberá a Carl Gustav Jung o papel inquestionável de ampliar os estudos da imaginação simbólica na arte, alargando a noção de inconsciente. O psiquiatra suíço descobre o inconsciente individual e coletivo povoados por arquétipos, repletos de imagens primordiais que o artista deforma para que sejam compreendidas pelo seu tempo procedimento que faz do artista um educador de sua época, conclui Jung:

Este é o segredo da ação da arte. O processo criativo consiste (até onde nos é dado segui-lo) numa ativação inconsciente do arquétipo e numa elaboração e formalização na obra acabada. De certo modo a formação da imagem primordial é uma transcrição para a linguagem do presente pelo artista, dando novamente a cada um a possibilidade de encontrar o acesso às fontes mais profundas da vida que, de outro modo, lhe seria negado. É aí que está o significado social da obra de arte: ela trabalha continuamente na educação do espírito da época, pois traz à tona aquelas formas das quais a época mais necessita. (JUNG, 1991, p. 71).

Por fim, nas primeiras décadas do século XX, todas estas discussões sobre o mito e a imaginação simbólica assumem uma capital importância no campo dos estudos antropológicos. Atendendo ao espírito do tempo, pela iniciativa da intelectual e artista 
Peregrinas e inauditas invenções: primeiros caminhos da imagem

holandesa Olga Fröebe-Kapteyn, formou-se o chamado Círculo de Eranos, um encontro anual em que pesquisadores das mais diversas áreas de investigação reuniam-se, durante uma semana do verão europeu, para partilharem saberes e debaterem ideias na Casa Gabriella, residência que Olga possuía às margens do lago Maggiore em Ascona, na Suíça, tendo Jung como patrono espiritual.

A visão da anfitriã era promover um evento interdisciplinar, que desse voz a pensadores de diferentes áreas de saber que, unificados no interesse pelo mito, pelo simbólico e pelo religioso, colocassem em diálogo o pensamento ocidental e o pensamento oriental. O primeiro ciclo dos encontros de Eranos foi notavelmente longevo, indo de 1933 até 1988, e colocou em contato figuras seminais, tais como o próprio Jung, além de Rudolf Otto, Paul Tilich, Henry Corbin, Károly Kerényi, D. T. Suzuki, Heinrich Zimmer, Joseph Campbell, Mircea Eliade, Gilbert Durand entre vários outros. Por sua vez, vários destes estudiosos trouxeram para o debate em Eranos as ideias de outros importantes nomes que não estiveram lá fisicamente, notadamente se fizeram sentidas as influências de Ernst Cassirer, Claude Lévi-Strauss, Gaston Bachelard e Paul Ricouer. Ao longo deste tempo, teria havido três fases observáveis nos encontros (CARVALHO, apud. FERREIRA; SILVEIRA, 2015): de 1933-1946, sob a liderança de Jung, Eranos voltou-se sobretudo para o exercício da Mitologia Comparada. Num segundo momento, de 1947 a 1961, a Antropologia Cultural toma a frente, destacando-se Eliade, Corbin e Campbell. Finalmente, de 1962 a 1988, seria a fase da "Hermenêutica Simbólica" ou "Antropologia Hermenêutica", sobressaindo nomes como Durand e Andrés Ortiz-Osés.

Desde 1960, Durand se empenhou em fundar o Centro de Pesquisas do Imaginário, ajudando a congregar novos pensadores de diferentes países, interessados em explorar a vertente de uma nova antropologia, que pudesse conceber uma ciência do homem menos cartesiana e fragmentada do que aquela que nos foi legada pelo racionalismo clássico. Este novo veio tem sido chamado comumente de Escola de Grenoble (referência à comuna francesa onde Durand foi professor por longos anos). Seguindo o veio aberto por Durand, surgiram nomes como Jean-Jacques Wunemburger, Alain Verjat e Michel Maffesoli.

Como se vê então, o campo dos Estudos do Imaginário se constitui e se consolida a partir de meados do século XX, amparado por um já considerável legado crítico-reflexivo, ao qual inúmeras contribuições de alto valor têm sido acrescentadas desde então. No entanto, nem sempre são conhecidas suas intervenções no campo acadêmico brasileiro, 
Peregrinas e inauditas invenções: primeiros caminhos da imagem

especialmente no campo literário, muito embora já seja possível encontrar sólidos estudos realizados pelos pesquisadores nacionais. De fato, as possibilidades de abordagem no campo do imaginário para a literatura são muitas e fecundas, como mostra este primeiro número da Téssera.

Abrindo os trabalhos, em "Fundamentos metodológicos do imaginário: mitocrítica e mitanálise", Alberto Filipe Araújo e Rogério de Almeida discutem sobre os métodos da mitocrítica e da mitanálise, numa instigante comparação que explicita as relações e as diferenças entre ambos, além de fazerem algumas aplicações exemplares. Finalmente, os autores encerram com uma ponderação sobre os limites da metodologia durandiana, buscando superá-los a partir de proposições assentadas na hermenêutica de Paul Ricouer.

“A importância social e simbólica do mito: da antiguidade clássica ao estabelecimento da mitologia como ciência”, de Ana Maria Saldanha, oferece uma síntese do percurso do mito na história da cultura ocidental, preocupando-se ainda com o legado de reflexões e de estudos a ele dedicados, desde os pensadores pré-socráticos, passando por Platão e Aristóteles, pelo medievo, pela Renascença, pelo Iluminismo e pelo Romantismo até o estabelecimento de uma ciência da mitologia por Max Müller, no final do século XIX. ${ }^{4}$

Em “A jornada do herói e da heroína: uma discussão analógica à luz da mitopsicocrítica", Maria Goretti Ribeiro e Ana Maria Leal Cardoso investigam a feição própria que tomou a heroína em seu processo de individuação, promovendo, assim, uma releitura do comportamento padrão, cujo modelo é o herói traçado por Campbell. Com base nos estudos de Ellen Douglas, Carol Christ e Annis Pratt, as autoras mostram que as mulheres criam mundos alternativos para o desenvolvimento de sua consciência.

Geam Karlo-Gomes investiga em "Soteriologia no romance Assunção de Salviano, de Antonio Callado", como a obra calladiana "aglutina elementos simbólicos, arquetípicos e míticos da Bíblia Judaico-cristã" para construir a imagem da figura messiânica de Manuel Salviano. Na trama, “de pregação em pregação, Salviano insiste numa pedagogia do direito da terra, através da inspiração na dimensão arquetípica da Grande Mãe, Tellus Mater, e do retorno à Idade de Ouro", proposta que acorda nos sertanejos a possibilidade da bemaventurança. Carl Gustav Jung, Mircea Eliade e Northrop Frye são a bibliografia básica desse estudo.

\footnotetext{
${ }^{4}$ Ressalte-se que se trata da primeira parte de um estudo maior, cuja continuação - fazendo a abordagem a partir do século XX - será publicada no segundo número da Téssera.
} 
Peregrinas e inauditas invenções: primeiros caminhos da imagem

Em "Estudo dos mitos e da construção narrativa em J. R. R. Tolkien”, Emanuelle Garcia Gomes e Fernanda Aquino Sylvestre tomam por base central as pesquisas do mitólogo Joseph Campbell, para analisar como a presença dos elementos míticos nos textos do escritor inglês conferem-lhe densidade semântica. $\mathrm{O}$ artigo evidencia o quanto a base estrutural mítica do texto de Tolkien permite que verdades morais sejam inscritas no plano da ficção de fantasia por ele elaborada, confirmando o poder do mito em criar sentidos para a existência humana.

O artigo "Manifestação e ambientação do insólito ficcional em Psicose, de Robert Bloch”, de Carla Helena Lange e Mauricio Cesar Menon, foge ao escopo teórico dessa revista, mas está aqui inserido pela divisa com que os elementos insólitos da obra de Robert Bloch e do filme de Alfred Hitchcok com o campo do imaginário: espaço, elementos internos, atmosfera, vão criando um ambiente de horror que desperta os medos mais primitivos. Estão na base teórica da pesquisa Tzvetan Todorov, Remo Ceserani, H.P. Lovecraft e Edgar Allan Poe.

Em "Medos aquáticos: uma poética do horror líquido em H. P. Lovecraft”, os autores Marcos Lampert Varnieri, Heitor Tomé da Rosa Filho e Regina da Costa da Silveira recorrem a Gaston Bachelard para uma análise do elemento água no contista Lovecraft: "Trata-se da seleção de imagens aquáticas, próprias à imaginação material em diferentes contos de H.P. Lovecraft.” Desta forma, as imagens da água maléfica, parada e escura vão imprimindo à narrativa um caráter tenebroso e devastador.

Maria de Fátima Gonçalves Lima e Jussiara Moema Ramos de Oliveira desenvolvem, em "Epopeia dos sertões de William Agel de Mello: uma incursão no imaginário e ecoficção do cerrado de Goiás", uma investigação sobre a imagem a partir de Bachelard e Durand. As pesquisadoras exploram, sobretudo, a ideia durandiana de constelação simbólica a partir dos isomorfismos imagéticos. Elas ainda situam Agel de Mello como um autor que "assinala o espaço do cerrado catalano como matéria de arte, reflexão e imaginação sobre a cultura do povo, das lendas, dos mitos, a linguagem e, de maneira especial, da fauna e da flora dos ermos goianos, com seus caminhos e descaminhos".

Danielle Perin Rocha Pitta, pioneira dos estudos do imaginário na academia brasileira, traça um painel expositivo das pesquisas realizadas entre nós em "Imaginário: derivações de métodos no Brasil”. O texto apresenta a variedade das investigações empreendidas, assim como revela a amplitude geográfica dos grupos e núcleos de estudiosos 
Peregrinas e inauditas invenções: primeiros caminhos da imagem

dedicados à imaginação simbólica no país, indicando as múltiplas possibilidades da aplicação de seu aparato teórico-metodológico numa cultura tão miscigenada quanto a nossa. A autora relata ainda como derivações de métodos têm sido criadas a partir de estudos aqui desenvolvidos, notadamente em arquitetura e urbanismo, o que confirma a importância deste campo teórico para o pensamento brasileiro, e vice-versa.

Por fim, encerra este número uma valiosa entrevista com Ana Maria Lisboa de Mello, mentora dos estudos do imaginário aplicados à literatura no Brasil, cujo estudo Poesia $e$ imaginário, sobre a obra de Cecília Meireles, já é um clássico. Questionada pela Téssera e por integrantes do GT da Anpoll "Imaginário, representações literárias e deslocamentos culturais", Ana Mello responde mapeando e elucidando, com generosidade, os entrecruzamentos que compõem um multifacetado campo teórico-metodológicointerpretativo que se tem construído graças à compreensão e valorização do homem como ser imaginante.

É neste quadro que a revista Téssera se insere, abrindo um novo espaço para divulgação da produção intelectual balizada pelos estudos do imaginário, em suas várias correntes e afluentes, junto à academia brasileira. Muito embora seu enfoque esteja voltado para o campo dos estudos literários, visto que se trata de uma revista ligada à Anpoll (Associação Nacional de Pós-Gradução e Pesquisa em Letras e Línguistica), não se poderia deixar de afirmar aqui também o caráter inerente de interdisciplinaridade que se coloca no horizonte de todo pesquisador disposto a peregrinar pelas sendas "divinatórias" da imaginação simbólica.

\section{Referências}

ADDISON, Joseph. "Sobre os prazeres da imaginação". In: SOUZA, Roberto Acízelo de (Org.). Do mito das musas à razão das letras - textos seminais para os estudos literários (século VIII a. C. - século XVIII). Chapecó: Argos, 2014.

ALBERTS, B.; JOHNSON, A.; LEWIS J. Organização interna da célula: Estrutura da membrana. 4. ed. Porto Alegre: Artmed, 2004.

BACON, Francis. "A poesia no conjunto do conhecimento". In: SOUZA, Roberto Acízelo de (Org.). Do mito das musas à razão das letras - textos seminais para os estudos literários (século VIII a. C. - século XVIII). Chapecó: Argos, 2014.

BOCCACCIO, Giovani. "Louvor da poesia”. In: SOUZA, Roberto Acízelo de (Org.). Do mito das musas à razão das letras - textos seminais para os estudos literários (século VIII a. C. - século XVIII). Chapecó: Argos, 2014.

BRETON, André. Manifesto do Surrealismo (1924). Acesso: http://www.culturabrasil.org/breton.htm Consultado em 11 nov 2018. 
Peregrinas e inauditas invenções: primeiros caminhos da imagem

CARLYLE, Thomas. "Símbolos". In: SOUZA, Roberto Acízelo de (Org.). Uma ideia moderna de literatura - textos seminais para os estudos literários (1688-1922). Chapecó: Argos, 2011.

DURAND, Gilbert. As estruturas antropológicas do imaginário: Introdução à arquetipologia geral. São Paulo: Martins Fontes, 2002.

O imaginário: Ensaio acerca das ciências e da filosofia da imagem. 3. ed. Rio de Janeiro: DIFEL, 2004.

EMERSON, Ralph Waldo. "O poeta”. In: SOUZA, Roberto Acízelo de (Org.). Uma ideia moderna de literatura - textos seminais para os estudos literários (1688-1922). Chapecó: Argos, 2011.

ERANOS FOUNDATION. "Who we are: History and Meaning of ERANOS". www.eranosfoundation.org/history.htm. Consultado em 20 nov 2018.

FERREIRA, Amauri Carlos; SILVEIRA, Luiz Henrique Lemos. "Do Círculo de Eranos à construção do simbólico, em Carl Gustav Jung". Psicologia USP. 2015. www.scielo.br/pdf/pusp/v26n2/0103-6564-pusp-26-02-00259.pdf. Consultado em 21 nov $\underline{2018}$

GRAVINA, Gianvincenzo. "Da razão poética”. In: SOUZA, Roberto Acízelo de (Org.). Do mito das musas à razão das letras - textos seminais para os estudos literários (século VIII a. C. - século XVIII). Chapecó: Argos, 2014.

HERÁCLITO, de Éfeso. Heráclito: fragmentos contextualizados. Tradução, apresentação e comentário de Alexandre Costa. São Paulo: Odysseus Editora, 2012.

JUNG, Carl Gustav. "Relação da psicologia analítica com a obra de arte". O espírito na arte e na ciência. Petrópolis: Vozes, 1991.

LÖWY, Michael; SAYRE, Robert. Revolta e melancolia: O romantismo na contramão da modernidade. Petrópolis, RJ: Vozes, 1995.

NOVALIS. Pólen - Fragmentos, diálogos, monólogo. Tradução, apresentação e notas de Rubens Rodrigues Torres Filho. São Paulo: Iluminuras, 2001.

SCHABERT, Tilo. From Olga Froebe-Kapteyn to the Amici di Eranos. On the history of the Eranos-Tagungen at Ascona (2011). www.eranos.org/content/pdf/History_of_Eranos_Tagungen.pdf. Consultado em 20 nov 2018.

SCHLEGEL, Friedrich. Conversa sobre poesia e outros fragmentos. São Paulo: Iluminuras, 1994.

SIDNEY, Philip. "Elogio da poesia”. In: SOUZA, Roberto Acízelo de (Org.). Do mito das musas à razão das letras - textos seminais para os estudos literários (século VIII a. C. século XVIII). Chapecó: Argos, 2014.

SOUZA, Roberto Acízelo de (Org.). Do mito das musas à razão das letras - textos seminais para os estudos literários (século VIII a. C. - século XVIII). Chapecó: Argos, 2014. 